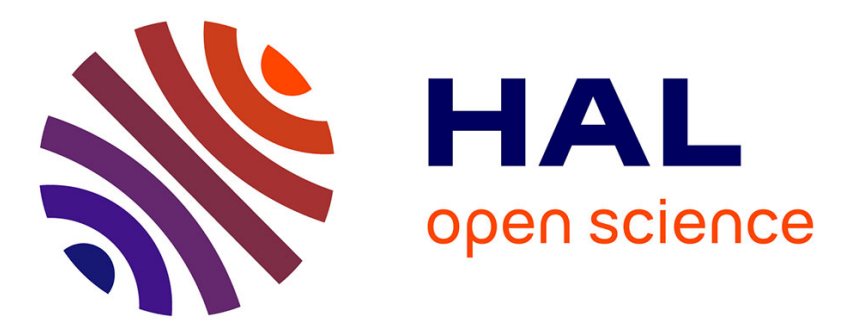

\title{
Unravelling the phenology of Ixodes frontalis, a common but understudied tick species in Europe
}

\author{
Albert Agoulon, Thierry Hoch, Dieter Heylen, Karine Chalvet-Monfray, \\ Olivier Plantard
}

\section{- To cite this version:}

Albert Agoulon, Thierry Hoch, Dieter Heylen, Karine Chalvet-Monfray, Olivier Plantard. Unravelling the phenology of Ixodes frontalis, a common but understudied tick species in Europe. Ticks and Tick-borne Diseases, 2019, 10.1016/j.ttbdis.2018.12.009 . hal-03115299

\section{HAL Id: hal-03115299 \\ https://hal.inrae.fr/hal-03115299}

Submitted on 26 Oct 2021

HAL is a multi-disciplinary open access archive for the deposit and dissemination of scientific research documents, whether they are published or not. The documents may come from teaching and research institutions in France or abroad, or from public or private research centers.
L'archive ouverte pluridisciplinaire HAL, est destinée au dépôt et à la diffusion de documents scientifiques de niveau recherche, publiés ou non, émanant des établissements d'enseignement et de recherche français ou étrangers, des laboratoires publics ou privés.

\section{다)(1) $\$$}

Distributed under a Creative Commons Attribution - NonCommercial| 4.0 International 
1 Unravelling the phenology of Ixodes frontalis, a common but understudied tick

2 species in Europe.

3 Albert Agoulon ${ }^{a},{ }^{*}$, Thierry Hoch ${ }^{a}$, Dieter Heylen ${ }^{b, c}$, Karine Chalvet-Monfrayd, Olivier

$4 \quad$ Plantarda

5 a BIOEPAR, INRA, Oniris, 44307, Nantes, France

6 b Interuniversity Institute for Biostatistics and statistical Bioinformatics, Hasselt

7 University, Diepenbeek, Belgium

8 c Department of Ecology and Evolutionary Biology, Princeton University, Princeton, NJ,

$9 \quad$ United States of America

d EPIA, INRA, VetAgro Sup, 63122, Saint-Genes-Champanelle, France

* Corresponding author. Tel.: 0033 240687699. Fax: 0033240687751.

E-mail address: albert.agoulon@oniris-nantes.fr

\section{Abstract:}

Tick-borne diseases have a complex epidemiology that depends on different ecological communities, associating several species of vertebrate hosts, vectors and pathogens.

While most studies in Europe are focused on Ixodes ricinus, the common sheep tick, other Ixodes species may also be involved in the transmission or maintenance of different pathogens. In this study, we describe for the first time the activity pattern of $I$. frontalis, an understudied but widespread tick species associated with several common bird species in Europe. Questing ixodid tick stages (larvae, nymphs and adults) of both $I$.

21 frontalis and I. ricinus were monitored by the drag sampling method over three years at the same locations in Western France. Differential activities were observed depending on I. frontalis life stages: nymphs and adults were present sporadically on the ground 
24 throughout the year, while larvae exhibited a marked peak of activity around October-

25 November with tens or even hundreds of individuals per $\mathrm{m}^{2}$, followed by a slow

26 decrease in winter. Larvae were completely absent in summer, which contrasts with the

27 high numbers of I. ricinus larvae at this time of the year. The vegetation and the litter

28 where the two tick species were found also exhibited marked differences, with $I$.

29 frontalis mostly collected under bamboo bushes.

Keywords:

Vector-borne diseases, bird ectoparasites, Ixodes ricinus, drag sampling, questing stages, population dynamics

\section{Introduction}

Vector-borne diseases constitute a major concern for both human and animal health. In temperate zones, hard ticks are considered to be the most important vectors in terms of diversity of pathogens, including zoonotic agents (such as Borrelia burgdorferi sensu lato, Anaplasma phagocytophilum, tick-borne encephalitis virus, Babesia spp.). They are also the vectors with the highest economical and medical impact on animals and Man (McCoy and Boulanger, 2015; Sonenshine, 1993). The transmission cycles of tick-borne pathogens are complex, involving generally several host species and sometimes more than one tick species (Estrada-Peña and de la Fuente, 2014; Kurtenbach et al., 2006; Mannelli et al., 2012; McCoy and Boulanger, 2015). Therefore, the study of a particular tick-borne pathogen requires an integrated community approach, in a diversity of host and tick species. 
European research has only recently started to thoroughly investigate the role of tick species other than I. ricinus in the transmission of I. ricinus-associated pathogens (Heylen et al., 2017b, 2014b, 2013; Jahfari et al., 2014; Obsomer et al., 2013). In Europe, the generalist I. ricinus is the most important vector to which humans are exposed, but some of the pathogens carried by this species can originate from other tick species, where they may exhibit a higher prevalence (Heylen et al., 2017b; Literak et al., 2015). When I. ricinus shares the hosts on which other tick species feed, pathogens can be bridged towards humans (Bown et al., 2008; Heylen et al., 2017b). Many of the other tick species within the tick community have been neglected, either because (i) they are rare or difficult to collect (e.g., endophilic ticks), (ii) they are easily misidentified (EstradaPeña et al., 2017a) or (iii) because they are not known to affect Man or animals of interest. This lack of interest leads to probable underestimation of their presence and of their real implication in pathosystems. The knowledge of basic ecological life history parameters of those understudied species, including their seasonal activity patterns, is crucial to understand the role of such tick species in tick-borne disease epidemiology. Ticks associated with birds, such as I. frontalis or I. arboricola, are of particular interest in this context because (i) they are known to carry several zoonotic pathogens such as Anaplasma phagocytophilum, Borrelia, or Rickettsia spp. (Heylen et al., 2017a), (ii) birds participate in the dissemination of ticks and their associated pathogens - at long distance but also in urbanised regions that are less accessible to migrating mammals (de la Fuente et al., 2015; Heylen, 2016) - and (iii) immature stages of I. ricinus - the most frequently reported species on humans - commonly feed on birds (Hornok et al., 2013), acting as a potential bridge species with possible transfer of pathogens between birds and mammals. 
In this article, we investigate seasonal activity patterns of the ornithophilic tick Ixodes frontalis, an abundant species from Europe (Estrada-Peña et al., 2017b), however with a poorly-investigated phenology of its free stages and with a largely unknown ecology (Heylen, 2016). I. frontalis is commonly found feeding on a great diversity of bird species that are shared with I. ricinus (Cringoli, 2005; Doby, 1998; Martyn, 1988; Monks et al., 2006; Norte et al., 2012). It has also been reported to exceptionally bite humans (Cull et al., 2018; Gilot et al., 1997). However, it has rarely been found questing on the ground (but see Barandika et al., 2006; Bona and Stanko, 2013; Ceballos et al., 2014; Doby, 1998; Gilot et al., 1997, 1995; Schorn et al., 2011), possibly because it is easily overlooked, especially for the larval stages that are difficult to identify due to their small size (Heylen et al., 2014a). I. frontalis is also known to be implicated in direct (i.e., without infectious agents) paralytic and mortality phenomena in certain birds (Mans et al., 2004; Monks et al., 2006), in the transmission of Chizé virus, fatal for birds (Chastel et al., 1999) and on the possible contribution to the maintenance of 'Candidatus Neoehrlichia mikurensis' (Movila et al., 2013), Anaplasma phagocytophilum (Jahfari et al., 2014) or Borrelia burgdorferi s.l. (Heylen et al., 2017a, 2013; Norte et al., 2013) in bird populations. As I. ricinus may bridge I. frontalis-related pathogens towards humans, the investigation of co-occurrences of both tick species in time and space, which will be described in this study, is of prime importance.

\section{Material and Methods}

A study site was selected in spring 2014 near Nantes $\left(47^{\circ} 19^{\prime} \mathrm{N}, 01^{\circ} 29^{\prime} \mathrm{W}\right)$ to survey exophilic hard tick densities on vegetation, estimated with the drag sampling method: a 
collected one day per month from June 2014 to May 2017 (Supplementary material I and II), during the second half of each month as regularly as possible (the collection could not occur on rainy days), by 1 to 4 operators, between 13:30 and 18:00. To collect questing ticks, ten marked transects of $10 \mathrm{~m} \times 1 \mathrm{~m}$ were chosen along trails covered by short grass or a leaf litter, with a minimum distance of $20 \mathrm{~m}$ between them (Fig. 1). Tick collection was repeated 3 times consecutively on the same marked transects, in order to collect more individuals and to improve accuracy in the assessment of tick abundance (Bord et al., 2014). On each transect, a $1 \mathrm{~m}^{2}$ white flannel cloth was slowly dragged $(0.5$ $\mathrm{m} / \mathrm{s}$ ) along the $10 \mathrm{~m}$ transect (Agoulon et al., 2012): ticks were counted, removed from the cloth with tweezers and stored alive (except larvae, which were stored in $70 \%$ ethanol for further identification from February 2015 onwards - see below) for further identification concerning stage and species according to the keys provided in Heylen et al. (2014a), Hillyard (1996) and Pérez-Eid (2007). Larvae were initially only counted and then discarded, without collection and identification. They were systematically collected and identified under an optical microscope (100x magnification) from February 2015 onwards.

The park was characterized by mainly deciduous trees (Quercus spp., Betula sp.), the presence of two ponds, a humid peaty soil (with Carex spp., Salix sp., Myrica gale) and several non-native plants along different parts of the trails, including bamboo (Phyllostachys spp.). The ten transects presented marked differences in terms of habitat: three transects (hereafter called "Transects with bamboo": ${ }^{\circ} 8$ to 10 ) were surrounded and overhung by bamboo and presented a litter covered with bamboo leaves (Fig. 1). The ground of the seven other transects (hereafter called "Transects without bamboo": $n^{\circ} 1$ to 7$)$ was either a litter of deciduous $\left(n^{\circ} 2, n^{\circ} 3, n^{\circ} 5\right)$ or coniferous needle leaves $\left(n^{\circ} 5\right)$, or short $(<15 \mathrm{~cm})$ grass $\left(n^{\circ} 1, n^{\circ} 4, n^{\circ} 6, n^{\circ} 7\right)($ Fig. 1$)$. 
120 A meteorological station was installed in January 2015 in a wooded part of the study site

121 (Fig. 1), recording hourly macroclimatic data exploited at the level of the whole site:

122 temperature, hygrometry and wind speed. Saturation deficit was calculated from

123 temperature and hygrometry according to Hartmann (1994). Mean values of these four

124 meteorological factors were considered as explanatory variables for analyses, at

125 different time intervals: 0-30 days, 0-10 days and 0-5 days prior to the day of tick

126 collection. Thus, twelve meteorological variables were considered, crossing mean values

127 of four factors and three time intervals (Table 1).

128 The temporal dynamics of the different stages of I. frontalis was described at the level of

129 the whole study site. For the larval stage, to evaluate the influence of meteorology, the

130 relationship between tick counts and meteorological variables was considered from

131 February 2015 to May 2017 by Spearman's rank correlation, and the best relationship

132 was selected according to the rho and its p-value. After log transformation of larval

133 counts $(\log ($ larval count +1$))$, because of the overdispersion of the data, a general linear

134 model was built to assess the influence of this selected meteorological variable, based on

$135 \mathrm{R}^{2}$. In parallel, to evaluate the influence of regular seasonal phenomena, the relationship

136 between I. frontalis larval counts and day length on the day of tick collection was

137 estimated in the same manner, leading to a similar model, hereafter called "seasonal

138 model". Finally, 4 models were compared, the best one being selected according to the

139 lowest Akaike information criterion (AIC): 1) “meteorological model” (1 selected

140 meteorological variable); 2) "seasonal model” (1 variable: day length); 3) “combined

141 model" (1 meteorological variable and day length); 4) "combined model with interaction"

142 (1 meteorological variable, day length and interaction between them). The same

143 statistical process was applied to the larval stage of I. ricinus for comparison. 
144 The distribution of the different stages of $I$. frontalis was described at the study site for

145 each transect to evaluate spatial distribution. It was compared to I. ricinus on two types

146 of transects: with bamboo versus without bamboo. Comparisons were performed by

147 bilateral Fisher's exact test. All analyses were carried out in R version 3.4.1 (R Core

148 Team, 2017).

\section{3. Results}

151 Temporal dynamics of I. frontalis

152 From September to November 2014, an increase in the density of questing larvae was

153 observed on transect $n^{\circ} 9$ (i.e., 14 larvae in September, 1230 in October, more than 3000

154 (rough count) in November and 466 in December 2014). As at that time of the study

155 larvae were assumed to belong to I. ricinus, they were just counted and discarded

156 without prior identification. In January 2015 , larvae of transect $n^{\circ} 9(n=490)$ were kept

157 and all were identified as I. frontalis (Fig. 2). Since that date, larvae from the whole study

158 site were then stored and identified for the remaining 28 months of the study (from

159 February 2015 to May 2017). Larval questing seasonality of $I$. frontalis could therefore

160 be assessed for that period: a marked peak of activity of I. frontalis larvae was observed

161 around October-November, followed by a slow decrease in winter and by the absence of

162 larvae in summer (Fig. 3a and Supplementary material I). Assuming that most of the

163 larvae collected earlier than January 2015 on transect $n^{\circ} 9$ belonged to I. frontalis

164 emphasizes this observed seasonality.

165 All meteorological variables were correlated to I. frontalis larval counts, except mean

166 wind speed. The best correlation concerned mean temperature over 10 days prior to 
tick collection (Table 1: Spearman's rank correlation rho=-0.6721; $\mathrm{p}$-value $=8.955 \mathrm{x}$ $\left.10^{-5}\right)$ : larvae could be abundant $(n>50)$ only when the mean temperature did not rise above $12^{\circ} \mathrm{C}$ over the previous 10 days $\left(\mathrm{R}^{2}\right.$ of the corresponding meteorological model=0.4693)(Fig. 4a). Day length was more correlated to larval counts (Spearman's rank correlation rho=-0.8078; $\mathrm{p}$-value $\left.=2.027 \times 10^{-7}\right)$ : larvae could be abundant $(\mathrm{n}>50)$ only when day length was below $12 \mathrm{~h}\left(\mathrm{R}^{2}\right.$ of the corresponding seasonal model $\left.=0.7531\right)$ (Fig. 4b). Meteorological and combined models (with or without interaction) exhibited a higher AIC than the seasonal model: the seasonal model was therefore selected for $I$. frontalis larvae, day length explaining $75.3 \%$ of the variance (Table 2). In comparison, the same process led to the selection of the meteorological model for I. ricinus larvae, mean temperature over 10 days prior to tick collection explaining $53.3 \%$ of the variance (Table 1, Fig. 4c and 4d, Table 2).

Besides I. frontalis larvae, for which thousands of individuals were found, only a few individuals of $I$. frontalis were identified at the nymphal $(n=28)$ and adult $(n=5$, all males) stages, with no clear seasonality (Fig. 3b, 3c and Supplementary material I). The relative rarity of those nymphal and adult stages of $I$. frontalis contrasts with the abundant collection of those stages for I. ricinus ticks (Supplementary material II).

\section{Spatial distribution of I. frontalis}

I. frontalis stages were clustered in 3 main transects $\left(n^{\circ} 8,9,10\right)$, with occasional presence (in decreasing order of importance) on transects $n^{\circ} 5, n^{\circ} 2, n^{\circ} 3, n^{\circ} 6$ or $n^{\circ} 7$ (Supplementary material I). The distribution of I. frontalis was significantly different from that of $I$. ricinus when considering on the one hand transects with bamboo $\left(\mathrm{n}^{\circ} 8\right.$ to 10) and on the other hand other transects ( $n^{\circ} 1$ to 7 ) (Fisher's exact tests: $p<2.2 \times 10^{-16}$ for larvae, $\mathrm{p}=6.9 \times 10^{-6}$ for nymphs and $\mathrm{p}=0.0161$ for adults)(Table 3 ). Considering the 
191

ratio of $I$. frontalis versus I. ricinus, places with bamboo appeared to be more favourable to I. frontalis, with the highest contrast for larvae (O.R.=842 (C.I.95\%=[427-1905])), followed by nymphs (O.R.=8 (C.I.95\%=[3-31]) ) and adults (O.R. incalculable because of the absence of $I$. frontalis adults on places without bamboo)(Table 3). On transects with bamboo, I. frontalis larvae were predominant compared to I. ricinus larvae (representing $82 \%$ of the captures), while I. frontalis nymphs and adults represented respectively $2 \%$ and $19 \%$ of the captures. On transects without bamboo, I. frontalis larvae and nymphs represented respectively $0.5 \%$ and $0.3 \%$ of the captures, and adults were absent (Table 3).

\section{Discussion}

Our study on the seasonal activity of exophilic hard ticks yielded unique information on $I$. frontalis, an ornithophilic tick with a largely unknown ecology. To the best of our knowledge, this is the first description of the phenology of the free stages of I. frontalis. The most remarkable feature consists in an abundant population of I. frontalis questing larvae during autumn-winter. Moreover, the distribution of I. frontalis appeared highly aggregated, with favourable sites consisting in transects surrounded and overhung by bamboo.

\section{Abundance and recurrence of questing stages of I. frontalis}

I. frontalis was firmly established at our study site, as evidenced by long-term presence (up to 36 months, from June 2014 to May 2017) of the three questing developmental stages, with 2218 confirmed I. frontalis larvae (from January 2015 to May 2017: Supplementary material I), 28 nymphs and 5 adults (males). To the best of our 
214 knowledge, this abundance has never been described before for I. frontalis questing ticks, 215 especially for the larval stage. In other studies in Europe, I. frontalis has been collected 216 by drag sampling, but only at the nymphal and adult stages (France: Doby, 1998; Gilot et 217 al., 1997, 1995 - Spain: Barandika et al., 2006 - Germany: Schorn et al., 2011 - Slovakia:

218 Bona and Stanko, 2013 - Italy: Ceballos et al., 2014). Therefore, I. frontalis questing 219 larvae may be more abundant than one would assume, due to confusion with I. ricinus 220 (Heylen et al., 2014a).

221 Phenology of I. frontalis

222 In our study, questing adults and nymphs were present sporadically throughout the year.

223 The larval stage, however, showed a marked seasonality, with an onset of questing 224 activity in September, followed by a peak in October-November, a slow decrease in 225 winter and an absence of activity in summer. Current literature reports only on the 226 phenology of host-feeding individuals in the wild (Doby, 1998; Norte et al., 2015, 2012). 227 Doby (1998) described the feeding activity of I. frontalis (by the time synonymized with 228 «Ixodes pari ») on blackbirds (Turdus merula) in France. The three parasitic life stages 229 were found constantly between late autumn and early winter, but not during summer. 230 The studies in Portugal by Norte et al. $(2015,2012)$ found that feeding activity takes 231 place between October and March. Larval activity peaks in November and secondary 232 peaks are observed in February or August, whereas nymphal peak activity is found in 233 December. The activity pattern of those bird-feeding ticks is consistent with the 234 autumnal peak of questing larvae found at our site (Fig. 3).

235 Life cycle duration of I. frontalis 
236 The understanding of the entire life cycle duration of I. frontalis is still debated. Doby

237 (1998) suggested a one-year life cycle, based on the developmental durations of ticks

238 obtained from experimental bird infestations. Also Heylen (unpublished results)

239 suggests that the life cycle may take only one year, if ticks have the opportunity to feed

240 soon after moulting. He monitored ticks in a breeding colony that was initiated for

241 vector-competence experiments (Heylen et al., 2017b, 2014b) and morphological

242 analysis (Heylen et al., 2014a). Still, if ticks have to wait for the host or enter diapause,

243 the life cycle will probably take much longer. A one-year life cycle is compatible with our

244 field data, where a clear seasonality is observed for the questing larvae (Fig. 3a), which

245 could correspond to the interval between two generations. However, as Doby (1998)

246 found the three stages on hosts at the same time (between late autumn and early

247 winter), it could suggest a longer life cycle. Further controlled monitoring studies under

248 quasi-natural conditions are clearly needed to deduce the real life cycle duration of $I$.

249 frontalis, by measuring the tick development duration of each stage and their longevity

250 between blood meals.

251 Determinants of the phenology of questing stages of I. frontalis

252 We found that day length, rather than meteorological conditions, showed the strongest

253 correlation with larval counts of I. frontalis: a higher abundance of larvae was observed

254 on short days, suggesting a main influence of regular annual determinants. On the

255 contrary, we found that the questing activity of the larval stage of $I$. ricinus was mainly

256 driven by temperature, with an increase in the population in warm conditions. Indeed,

257 questing behaviour in this species is known to be influenced by meteorological

258 conditions - at least for the nymphal stage (Cat et al., 2017; Jensen, 2000; Kiewra et al.,

259 2014; Perret et al., 2003, 2000; Schulz et al., 2014; Walker, 2001). Because I. frontalis 
260 larvae are active during autumn and winter, we assume that the determinant for the

261 phenology of this tick species may be different from I. ricinus. We hypothesize that the

262 autumn-winter peak of $I$. frontalis larvae may correspond to the feeding of female ticks

263 on birds after bird reproduction (i.e., in summer) during a short period. This would

264 induce a synchronization of egg development, with a fast increase in the larval

265 population, as we observe. It would be consistent with the observation in the UK of a

266 peak in August-September of tick-related syndrome cases on birds due to I. frontalis

267 adult females (Monks et al., 2006), even if the situation may be different in other parts of

268 the distribution area of I. frontalis (such as I. ricinus, showing a different phenology in

269 western versus central Europe: Kurtenbach et al., 2006). For I. ricinus, the feeding of

270 females is known to occur during a long spring period (Randolph 2004), leading to a less

271 synchronized egg development and hence perhaps a greater influence of temperature on

272 larval emergence in summer. However, for I. frontalis, alternative hypotheses such as

273 egg or larval diapause or delayed egg hatching cannot be excluded before conducting

274 additional investigations.

275 Spatial distribution of questing stages of I. frontalis

276 Some transects exhibited frequent high densities of $I$. frontalis, especially for the larval

277 stage. Despite being distant from each other, the transects shared the same physical

278 characteristics with bamboo surrounding and overhanging the ground. The literature

279 reports that the physical characteristics of the collection sites for questing I. frontalis are

280 very similar to biotopes where I. ricinus can be found (Ceballos et al., 2014; Cringoli et al.,

281 2005; Gilot et al., 1997, 1995; Schorn et al., 2011). To our knowledge, the presence of $I$.

282 frontalis in bamboo bushes has never been described before. At our study site, we

283 suspect that the abundance of $I$. frontalis under bamboo is a consequence of bird 
284 attendance. Bamboo may be a favourable place for birds to roost overnight, difficult to

285 reach for predators. However, bamboo does not seem favourable for bird nesting,

286 because of the lack of solid forked branches, hindering the attachment of nests. Thus, we

287 hypothesize that the timing of detachment of engorged female ticks under bamboo is

288 distinct from the reproduction period of birds, even if we have no data on the bird host

289 species involved for the maintenance of the population of $I$. frontalis at our study site. $I$.

290 frontalis is known to infest a wide range of birds, because virtually any bird species is

291 submitted to parasitism when it walks on the ground (Doby, 1998; Hornok et al., 2016).

292 A good candidate species could be the blackbird (Turdus merula), which has been

293 observed at the site. It presents both the highest infestation prevalence and the highest

294 tick burden in the literature (Doby, 1998; Norte et al., 2015). This point could be studied

295 in the future, along with potential pathogen transmission consequences.

296 Conclusion

297 We have demonstrated that I. frontalis and I. ricinus have different phenologies and

298 occupy distinct habitat types at our study site. Nevertheless, we have also shown that

299 they can co-occur both in time and space (even at a very limited spatial scale of $10 \mathrm{~m}^{2}$ ),

300 indicating a possibility for those two tick species to parasitize the same host individuals

301 and thus to share pathogens. We thus strongly encourage researchers to systematically

302 identify the larval stage of hard ticks found on the ground. Even if I. ricinus is the most

303 common species collected in Europe with the drag sampling method, I. frontalis may

304 have been underestimated, especially during autumn and winter. A pathogen such as

305 Borrelia turdi, belonging to the Borrelia burgdorferi s.l. group, can have a prevalence of

$30614.8 \%$ in some I. frontalis populations (Literak et al., 2015) and the vector competence

307 of I. ricinus for this Borrelia species has been recently demonstrated experimentally 
308 (Heylen et al., 2017b). The generalist tick I. ricinus could thus function as a bridging species from I. frontalis hosts, allowing some pathogens to spill over and reach hosts

310 other than birds, including humans or domestic animals. The spatio-temporal overlap

311 between I. ricinus and I. frontalis may also be influenced by the currently observed

312 climate change and thus influence the epidemiology of the tick-borne diseases

313 associated with those ticks, an issue that should be investigated through dedicated 314 studies.

\section{Declarations of interest}

317 None.

\section{Acknowledgments}

320 Our special thanks are addressed to the owner of the study site, Henri de Goué, who

321 accepted the installation of the meteorological station and the monthly sampling of ticks

322 on his property. We are also indebted to Frédéric Huard, from AgroClim Service Unit, F32384914 Avignon, for providing and installing the meteorological station. We thank also 324 Jean-Yves Audiart, Claire Bonsergent, Agnès Bouju-Albert, Romain Braud, Alessandra 325 Cafiso, Pierre Charrier, Marjorie Couton, Nathalie De la Cotte, Marion Dellinger, Héloïse 326 Duchêne, Axelle Durand, Caroline Hervet, Hadrien Jouanne, Yann Quenet, Claude Rispe 327 and Marielle Schleicher, who helped in collecting ticks. We are also grateful to the TMT328 REID group ("Tiques et Maladies à Tiques" group of the "Réseau Ecologie des 329 Interactions Durables") for discussion and support. This work received financial support 330 from the CC-EID project (métaprogramme "Adaptation of Agriculture and Forests to 
331 Climate Change" of the French National Institute for Agricultural Research (INRA)).

332 Dieter Heylen is funded by the Marie Sklodowska-Curie Actions (EU-Horizon 2020,

333 Individual Global Fellowship, project $n^{\circ}$ 799609) and the Fund for Scientific Research -

334 Flanders (FWO).

335

336

References

337

Agoulon, A., Malandrin, L., Lepigeon, F., Vénisse, M., Bonnet, S., Becker, C.A.M., Hoch, T.,

Bastian, S., Plantard, O., Beaudeau, F., 2012. A Vegetation Index qualifying pasture edges is related to Ixodes ricinus density and to Babesia divergens seroprevalence in dairy cattle herds. Vet. Parasitol. 185, 101-109.

Barandika, J.F., Berriatua, E., Barral, M., Juste, R.A., Anda, P., Garcia-Perez, A.L., 2006. Risk factors associated with ixodid tick species distributions in the Basque region in Spain. Med. Vet. Entomol. 20, 177-188.

Bona, M., Stanko, M., 2013. First records of the tick Ixodes frontalis (Panzer, 1795) (Acari, 347 Ixodidae) in Slovakia. Ticks Tick Borne Dis. 4, 478-481.

Bord, S., Druilhet, P., Gasqui, P., Abrial, D., Vourc'h, G., 2014. Bayesian estimation of abundance based on removal sampling under weak assumption of closed population with catchability depending on environmental conditions. Application to tick abundance. Ecol. Model. 274, 72-79.

354 Bown, K.J., Lambin, X., Telford, G.R., Ogden, N.H., Telfer, S., Woldehiwet, Z., Birtles, R.J., 355 2008. Relative importance of Ixodes ricinus and Ixodes trianguliceps as vectors 
for Anaplasma phagocytophilum and Babesia microti in field vole (Microtus agrestis) populations. Appl. Environ. Microbiol. 74, 7118-7125.

358

Cat, J., Beugnet, F., Hoch, T., Jongejan, F., Prangé, A., Chalvet-Monfray, K., 2017. Influence of the spatial heterogeneity in tick abundance in the modeling of the seasonal activity of Ixodes ricinus nymphs in Western Europe. Exp. Appl. Acarol. 71, 115-130.

Ceballos, L.A., Pintore, M.D., Tomassone, L., Pautasso, A., Bisanzio, D., Mignone, W., region, northwest Italy. Exp. Appl. Acarol. 64, 121-135.

Chastel, C., Chandler, L., Le Goff, F., Chastel, O., Tesh, R., Shope, R., 1999. Chizé virus, a new phlebovirus isolated in France from Ixodes (Trichotoixodes) frontalis. Acta virol. 43, 279-283.

Cringoli, G., Iori, A., Rinaldi, L., Veneziano, V., Genchi, C., 2005. Zecche. Mappe Parassitologiche. Rolando Editore, Napoli, 308 p.

Cull, B., Pietzsch, M.E., Hansford, K.M., Emma L. Gillingham, E.L., Medlock, J.M., 2018. Surveillance of British ticks: An overview of species records, host associations, and new records of Ixodes ricinus distribution. Ticks Tick Borne Dis. 9, 605-614. evolved associations that constitute a risk of infectious disease spread. Parasit Vectors 8, 
Doby, J.M., 1998. Contribution à la connaissance de la biologie de Ixodes (Trichotoixodes) pari Leach (=I. frontalis (Panzer))(Acari : Ixodidae), tique spécifique des oiseaux.

384 Acarologia 39, 315-324.

385

Estrada-Peña, A., de la Fuente, J., 2014. The ecology of ticks and epidemiology of tickborne viral diseases. Antiviral Res 108, 104-128.

Estrada-Peña, A., D'Amico, G., Palomar, A.M., Dupraz, M., Fonville, M., Heylen, D., Habela,

M.A., Hornok, S., Lempereur, L., Madder, M., Nuncio, M.S., Otranto, D., Pfäffle, M., Plantard,

comparative test of ixodid tick identification by a network of European researchers.

Ticks Tick Borne Dis. 8, 540-546.

Estrada-Peña, A., Mihalca, A.D., Petney, T.N. (Eds.), 2017b. Ticks of Europe and North

Africa - A Guide to Species Identification, Springer International Publishing, Cham.

Gilot, B., Doche, B., Degeilh, B., Guiguen, C., Pichot, J., 1995. Bases acarologiques pour

l'étude épidémiologique de la borréliose de Lyme : les populations d'Ixodes ricinus Linne, 1758 du Sud-Ouest français. Acarologia 36, 117-132.

402 Gilot, B., Beaucournu, J.C., Chastel, C., 1997. Collecte «au drapeau» et fixation sur

403 l'homme d'Ixodes (Trichotoixodes) frontalis (Panzer, 1795). Parasite 4, 197-199. 
Hartmann, D.L., 1994. Global Physical Climatology, Academic Press, San Diego, New York, Boston.

Heylen, D., 2016. Ecological interactions between songbirds, ticks, and Borrelia burgdorferi s.l. in Europe. In: Braks, M.A.H., van Wieren, S.E., Takken, W., Sprong, H. (Eds.), Ecology and prevention of Lyme borreliosis. Ecology and control of vector-borne diseases, Volume 4, Wageningen Academic Publishers, The Netherlands, pp. 91-101.

Heylen, D., De Coninck, E., Jansen, F., Madder, M., 2014a. Differential diagnosis of three common Ixodes spp. ticks infesting songbirds of Western Europe: Ixodes arboricola, I. frontalis and I. ricinus. Ticks Tick Borne Dis. 5, 693-700.

Heylen, D., Fonville, M., Docters van Leeuwen, A., Stroo, A., Duisterwinkel, M., van Wieren, S., Maria Diuk-Wasser, M., de Bruin, A., Sprong, H., 2017a. Pathogen communities of songbird-derived ticks in Europe’s low countries. Parasit Vectors 10, 497.

Heylen, D., Krawczyk, A., Lopes de Carvalho, I., Nuncio, M.S., Sprong, H., Norte, A.C., 2017b. Bridging of cryptic Borrelia cycles in European songbirds. Environ. Microbiol. 19, 1857-1867.

Heylen, D., Sprong, H., van Oers, K., Fonville, M., Leirs, H., Matthysen, E., 2014b. Are the specialized bird ticks, Ixodes arboricola and I. frontalis, competent vectors for Borrelia burgdorferi sensu lato? Environ. Microbiol. 16, 1081-1089.

429 Heylen, D., Tijsse, E., Fonville, M., Matthysen, E., Sprong, H., 2013. Transmission 
dynamics of Borrelia burgdorferi s.l. in a bird tick community. Environ. Microbiol. 15,

431

432

433

434

435

436

437

438

439

440

441

442

443

Jensen, P.M., 2000. Host seeking activity of Ixodes ricinus ticks based on daily consecutive flagging samples. Exp. Appl. Acarol. 24, 695-708.

Hillyard, P.D., 1996. Ticks of North-West Europe. Field Studies Council Ed., Shrewsbury, $178 \mathrm{p}$.

Hornok, S., Csörgő, T., de la Fuente, J., Gyuranecz, M., Privigyei, C., Meli, M.L., Kreizinger, Z., Gönczi, E., Fernández de Mera, I.G., Hofmann-Lehmann, R., 2013. Synanthropic birds associated with high prevalence of tick-borne rickettsiae and with the first detection of Rickettsia aeschlimannii in Hungary. Vector-Borne Zoon Dis. 13, 77-83.

Hornok, S., Flaisz, B., Takács, N., Kontschán, J., Csörgő, T., Csipak, Á., B. R. Jaksa, B.R., D. Kováts, D., 2016. Bird ticks in Hungary reflect western, southern, eastern flyway connections and two genetic lineages of Ixodes frontalis and Haemaphysalis concinna. Parasit Vectors 9, 101.

Jahfari, S., Coipan, E.C., Fonville, M., Docters van Leeuwen, A., Hengeveld, P., Heylen, D., Heyman, P., van Maanen, C., Butler, C.M., Földvári, G., Szekeres, S., van Duijvendijk, G., Tack, W., Rijks, J.M., van der Giessen, J., Takken, W., van Wieren, S.E., Katsuhisa Takumi, K., Sprong, H., 2014. Circulation of four Anaplasma phagocytophilum ecotypes in Europe. Parasit Vectors 7, 365. 
meteorological variables on the questing activity of Ixodes ricinus ticks in Lower Silesia, SW Poland. J. Vector Ecol. 39, 138-145.

458

459 Kurtenbach, K., Hanincová, K., Tsao, J.I., Margos, G., Fish, D., Ogden, N.H. 2006.

460 Fundamental processes in the evolutionary ecology of Lyme borreliosis. Nat Rev

461 Microbiol. 4, 660-669.

462

463 Literak, I., Norte, A.C., Núncio, M.S., de Carvalho, I.L., Ogrzewalska, M., Nováková, M.,

464 Martins, T.F., Sychra, O., Resendes, R., Rodrígues, P., 2015. Ticks on passerines from the 465 Archipelago of the Azores as hosts of borreliae and rickettsiae. Ticks Tick Borne Dis. 6, $466 \quad 607-610$.

Mannelli, A., Bertolotti, L., Gern, L., Gray, J., 2012. Ecology of Borrelia burgdorferi sensu lato in Europe: transmission dynamics in multi-host systems, influence of molecular processes and effects of climate change. FEMS Microbiol Rev. 36, 837-861.

Mans, B.J., Gothe, R., Neitz, A.W.H., 2004. Biochemical perspectives on paralysis and other forms of toxicoses caused by ticks. Parasitology 129, S95-S111.

Martyn, K.P., 1988. Provisional Atlas of the Ticks (Ixodoidea) of the British Isles.

476 Institute of terrestrial ecology, Cumbria.

478 McCoy, K.D., Boulanger, N. (Eds.), 2015. Tiques et maladies à tiques : biologie, écologie 479 évolutive, épidémiologie, IRD Editions (Collection Didactiques), Marseille. 
481 Monks, D., Fisher, M., Forbes, N.A., 2006. Ixodes frontalis and avian tick-related syndrome 482 in the United Kingdom. J. Small Anim. Practice 47, 451-455.

483

484 Movila, A., Alekseev, A.N., Dubinina, H.V., Toderas, I., 2013. Detection of tick-borne 485 pathogens in ticks from migratory birds in the Baltic region of Russia. Med. Vet. Entomol. 27, 113-117.

Norte, A.C., Lopes de Carvalho, I., Ramos, J.A., Gonçalves, M., Gern, L., Núncio, M.S., 2012.

Diversity and seasonal patterns of ticks parasitizing wild birds in western Portugal. Exp. Appl. Acarol. 58, 327-339.

Norte, A.C., Ramos, J.A., Gern, L., Núncio, M.S., Lopes de Carvalho, I., 2013. Birds as reservoirs for Borrelia burgdorferi s.l. in Western Europe: circulation of B. turdi and other genospecies in bird-tick cycles in Portugal. Environ. Microbiol. 15, 386-397.

495

Norte, A.C., da Silva, L.P., Tenreiro, P.J.Q., Felgueiras, M.S., Araújo, P.M., Lopes, P.B., Matos,

C., Rosa, A., Ferreira, P.J.S.G., Encarnação, P., Rocha, A., Escudero, R., Anda, P., Núncio, M.S., 498 Lopes de Carvalho, I., 2015. Patterns of tick infestation and their Borrelia burgdorferi s.l. infection in wild birds in Portugal. Ticks Tick Borne Dis. 6, 743-750.

501 Obsomer, V., Wirtgen, M., Linden, A., Claerebout, E., Heyman, P., Heylen, D., Madder, M., 502 Maris, J., Lebrun, M., Tack, W., Lempereur, L., Thierry Hance, T., Van Impe, G., 2013. 503 Spatial disaggregation of tick occurrence and ecology at a local scale as a preliminary 504 step for spatial surveillance of tick-borne diseases: general framework and health 
505 implications in Belgium. Parasit Vectors 6, 190-208.

506

507 Pérez-Eid, C., 2007. Les tiques : identification, biologie, importance médicale et

508 vétérinaire, Editions Tec \& Doc / EM Internationale, Paris.

509

510 Perret, J.-L., Guigoz, E., Rais, O., Gern, L., 2000. Influence of saturation deficit and

511 temperature on Ixodes ricinus tick questing activity in a Lyme borreliosis-endemic area

512 (Switzerland). Parasitol. Res. 86, 554-557.

513

514 Perret, J.-L., Guerin, P.M., Diehl, P.A., Vlimant, M., Gern, L., 2003. Darkness induces

515 mobility, and saturation deficit limits questing duration, in the tick Ixodes ricinus. J. Exp.

516 Biol. 206, 1809-1815.

517

518 R Core Team. R: a language and environment for statistical computing. Vienna: R

519 Foundation for Statistical Computing; 2017. http://www.rproject.org.

520

521 Randolph, S.E., 2004. Tick ecology: processes and patterns behind the epidemiological

522 risk posed by ixodid ticks as vectors. Parasitology 129, S37-S65.

523

524 Schorn, S., Schöl, H., Pfister, K., Silaghi, C., 2011. First record of Ixodes frontalis collected 525 by flagging in Germany. Ticks Tick Borne Dis. 2, 228-230.

526

527 Schulz, M., Mahling, M., Pfister, K., 2014. Abundance and seasonal activity of questing

528 Ixodes ricinus ticks in their natural habitats in southern Germany in 2011. J. Vector Ecol.

$52939,56-65$. 
531 Sonenshine, D.E., 1993. Biology of Ticks, Vols I and II, Oxford University Press, UK.

533 Walker, A.R., 2001. Age structure of a population of Ixodes ricinus (Acari: Ixodidae) in

534 relation to its seasonal questing. Bull. Entomol. Res. 91, 69-78.

535

Legends to figures

537 Fig. 1. Geographical position $\left({ }^{*}\right)$ of the study site in France (left). Aerial photograph of 538 the observatory with position $(\odot)$ of the meteorological station (center). Two transects, 539 illustrating transects without $\left(\mathrm{n}^{\circ} 1\right)$ or with $\left(\mathrm{n}^{\circ} 9\right)$ bamboo (right).

541 Fig. 2. Distinction of Ixodes frontalis (a) and Ixodes ricinus (b) at the larval stage (light 542 microscopy).

544 Ixodes frontalis larvae (a) have a marked protuberance on the front margin of the basis

545 of the capitulum, between palp and hypostome (black arrow), external spurs on coxa I, II

546 and III (grey arrows), and an internal spur on coxa I (white arrow).

547 Ixodes ricinus larvae (b) have a straight front margin of the basis of the capitulum,

548 between palp and hypostome (black arrow), small external spurs on coxa I and II (grey

549 arrows), and an internal spur on coxa I (white arrow).

551 Fig. 3. Temporal distribution of questing stages of Ixodes frontalis and Ixodes ricinus.

552 a) larvae, b) nymphs, c) adults. 
554 For larvae, the scale is logarithmic, and 1 was added to the counts (n): the baseline (« 1 » 555 on the Y axes) corresponds to the absence of larva. Note that larvae collected before $55627 / 01 / 2015$ were not identified, but (1) those collected on transect $n^{\circ} 9$ until $55729 / 12 / 2014$ are represented by «? » as they were presumed to belong to I. frontalis (see 558 text and Supplementary Material I and II), (2) and those collected on transect $\mathrm{n}^{\circ} 9$ on $55927 / 01 / 2015$ are represented by ${ }^{\Delta}$ as they were confirmed for the first time as I. frontalis. 560 From 18/02/2015 to 16/05/2017, all the transects were considered because larval

561 identification was systematic. For larvae only, shaded grey areas highlight the 562 seasonality of $I$. frontalis during autumn seasons. ${ }^{x}$ and a dashed black line represents $I$. 563 ricinus. $^{\circ}$ and a continuous red line represents I. frontalis.

565 Fig. 4. Relationship between mean temperature over 10 days prior to tick collection (a, 566 c) or day length (b, d) and Ixodes frontalis (a, b) or I. ricinus (c, d) larval counts (n+1).

568 The relationship between mean temperature (over 10 days prior to tick collection) and 569 Ixodes frontalis or I. ricinus larval counts (on the day of tick collection) was considered 570 from February 2015 to May 2017 (28 dates) for the whole observatory. The same set of 571 data was used for the influence of day length. To represent larval counts on a 572 logarithmic scale, 1 had to be added to the counts (n): the baseline (« 1 » on the $\mathrm{Y}$ axes) corresponds to the absence of larva. 


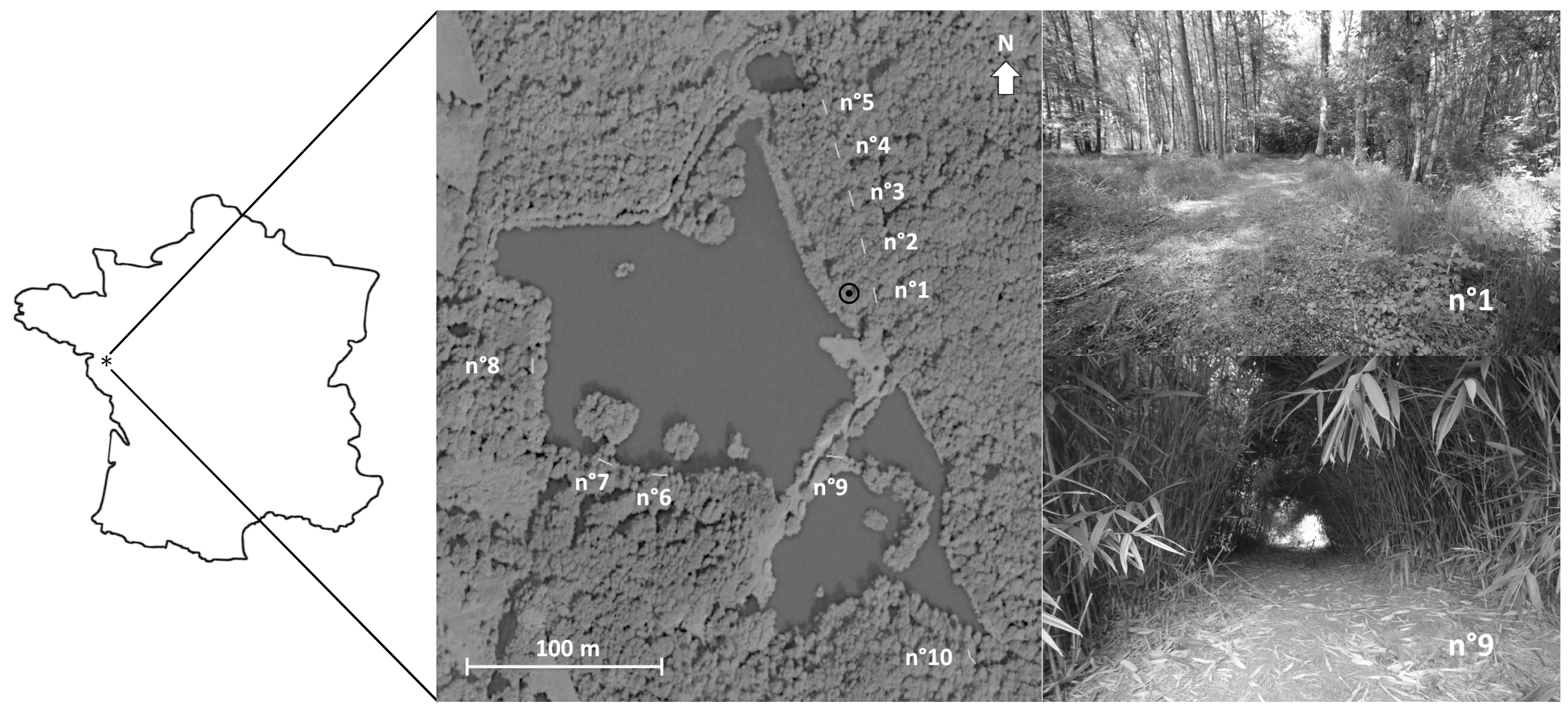


a)

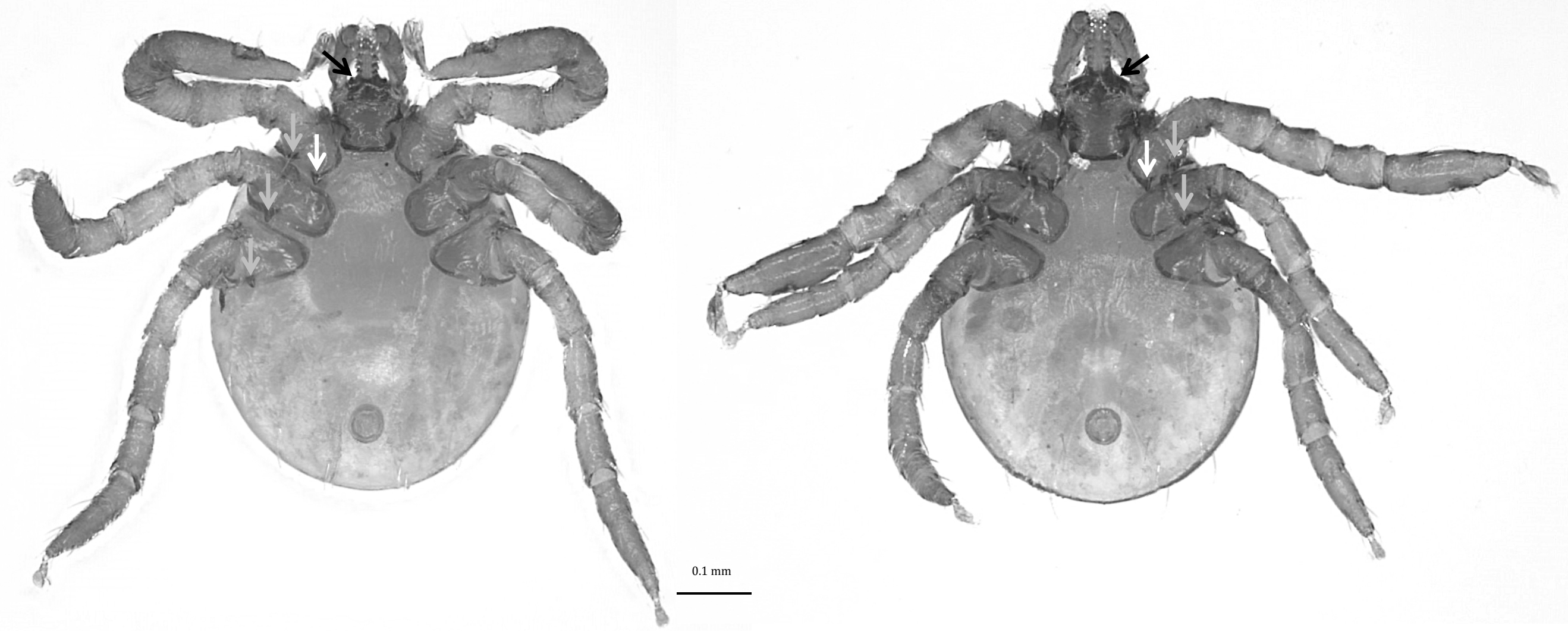


a)

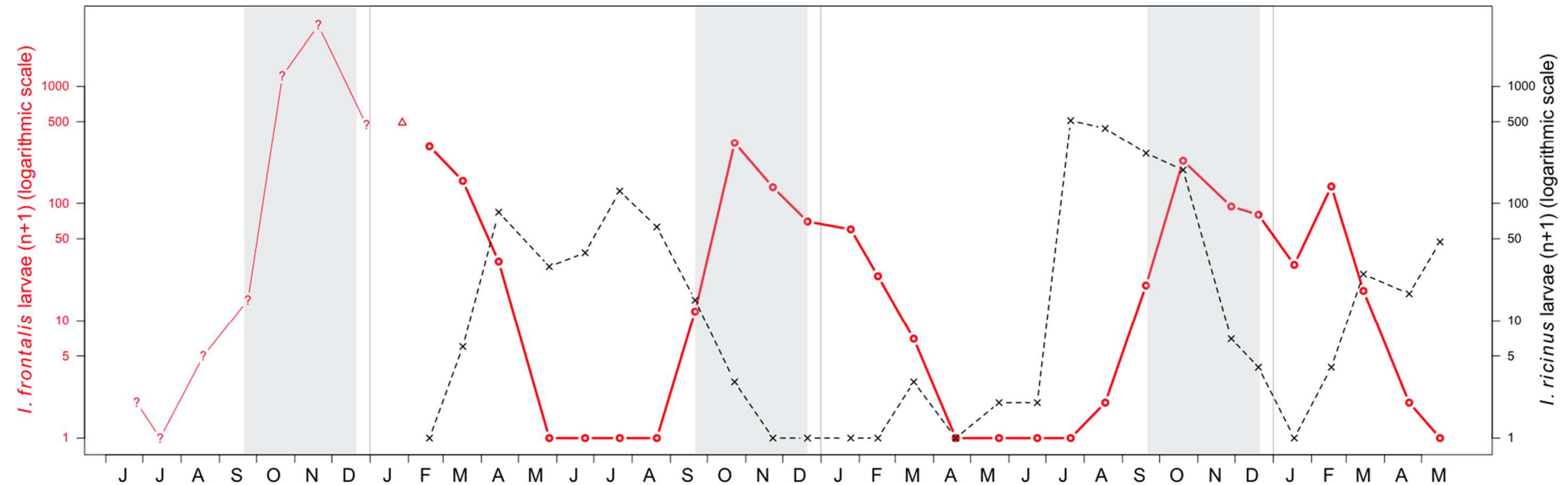

b)

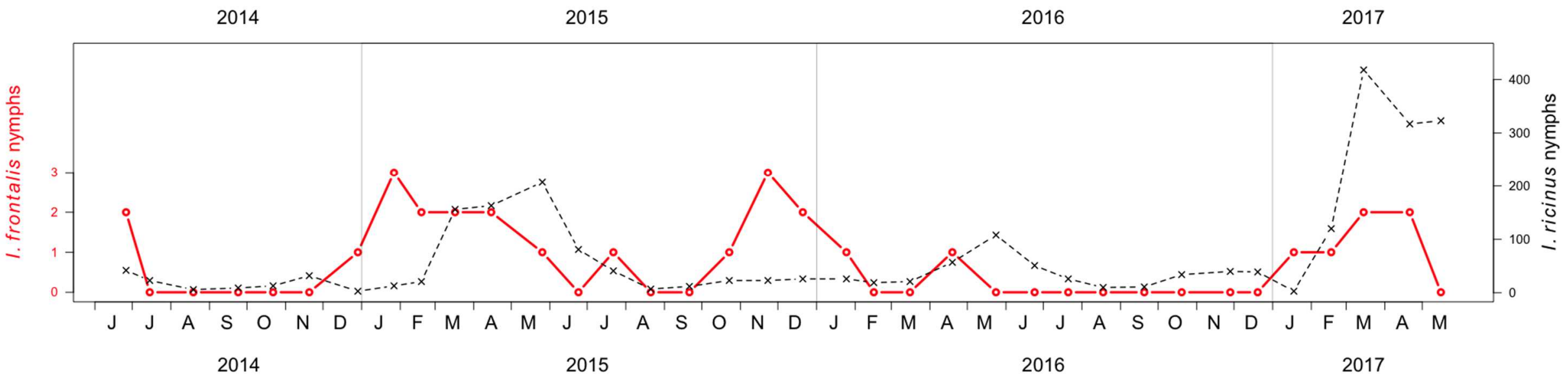

c)

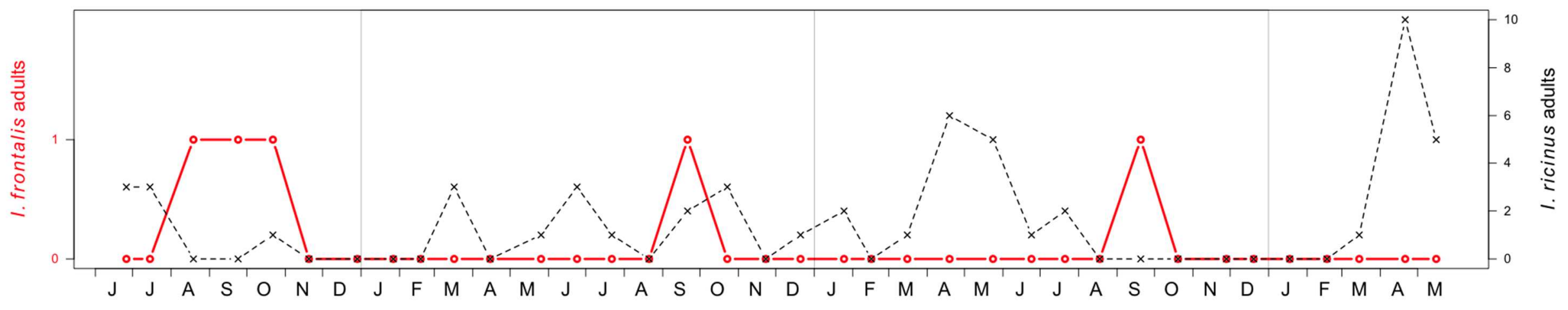


a)

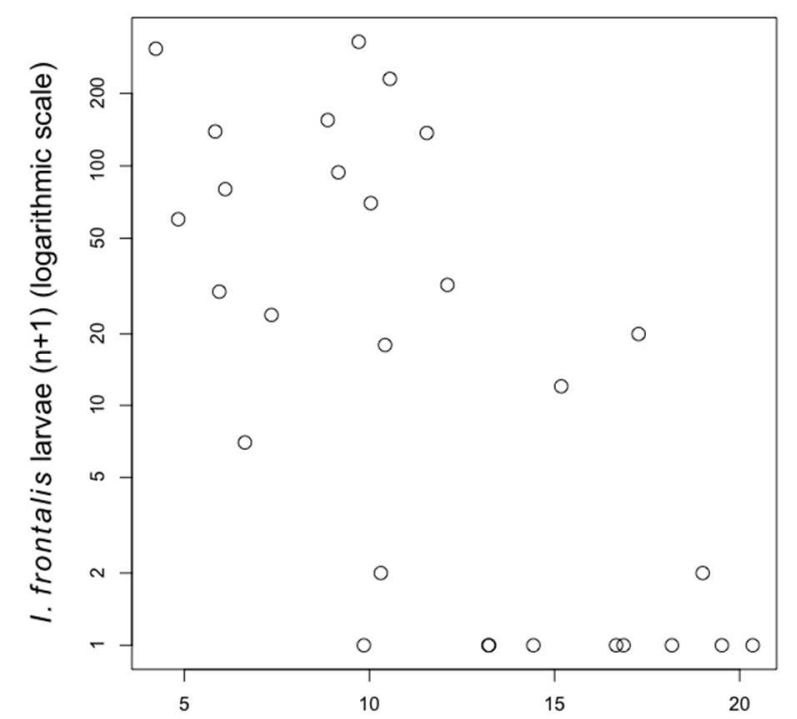

Mean temperature $\left({ }^{\circ} \mathrm{C}\right)$ over 10 days prior to tick collection

c)

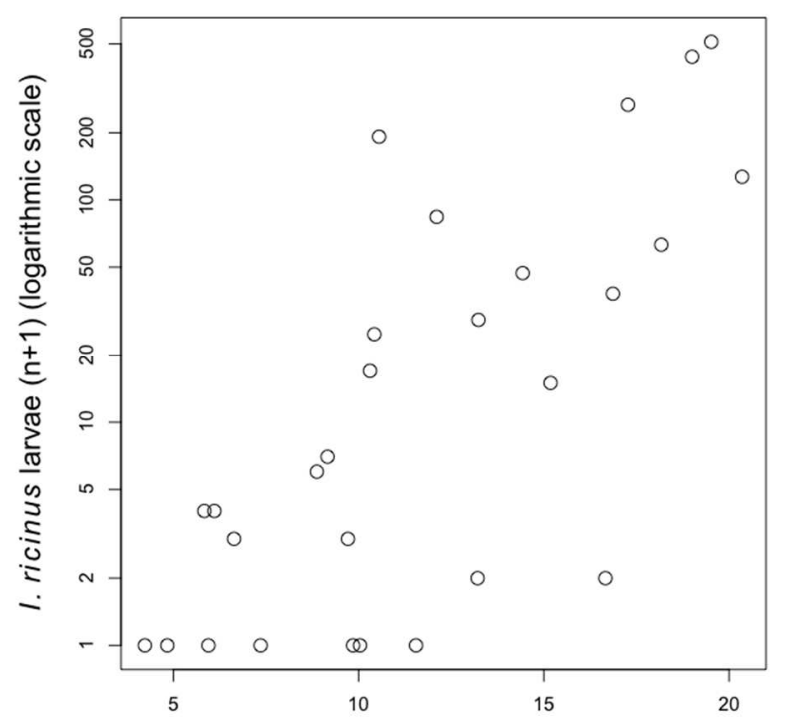

Mean temperature $\left({ }^{\circ} \mathrm{C}\right)$ over 10 days prior to tick collection b)

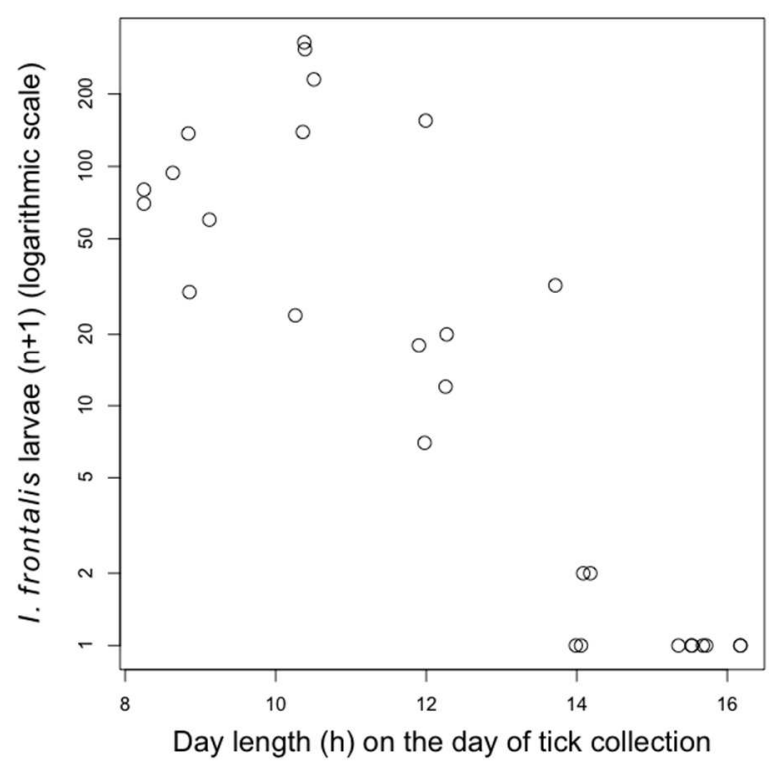

d)

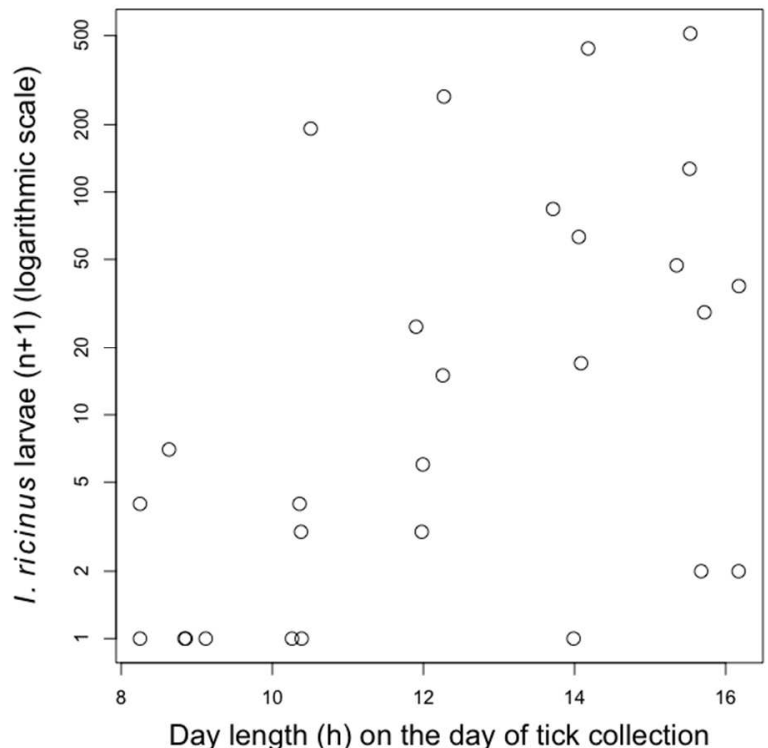




\section{Table 1}

Relationship between Ixodes frontalis or Ixodes ricinus larval counts and meteorological variables or day length, attested by Spearman's rank correlation.

a) Ixodes frontalis

\begin{tabular}{|c|c|c|c|}
\hline \multirow{2}{*}{ 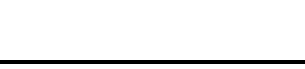 } & & & \\
\hline & 0-30 days* & 0-10 days* & $0-5$ days* \\
\hline Mean hygrometry & $\begin{array}{c}p=0.003 \\
\text { rho }=0.534\end{array}$ & $\begin{array}{c}\mathrm{p}=0.008 \\
\mathrm{rho}=0.494\end{array}$ & $\begin{array}{c}p=0.008 \\
\text { rho }=0.488\end{array}$ \\
\hline Mean temperature & $\begin{array}{c}\mathrm{p}=0.002 \\
\mathrm{rho}=-0.565\end{array}$ & $\begin{array}{c}p<0.001 \\
\text { rho }=-0.672\end{array}$ & $\begin{array}{c}\mathrm{p}<0.001 \\
\text { rho }=-0.645\end{array}$ \\
\hline Mean wind speed & $\begin{array}{c}\mathrm{p}=0.657 \\
\mathrm{rho}=-0.088\end{array}$ & $\begin{array}{c}p=0.407 \\
\mathrm{rho}=-0.163\end{array}$ & $\begin{array}{c}\mathrm{p}=0.597 \\
\mathrm{rho}=-0.104\end{array}$ \\
\hline $\begin{array}{c}\text { Mean saturation } \\
\text { deficit }\end{array}$ & $\begin{array}{c}p=0.001 \\
\text { rho }=-0.597\end{array}$ & $\begin{array}{c}\mathrm{p}<0.001 \\
\text { rho=-0.623 }\end{array}$ & $\begin{array}{c}\mathrm{p}<0.001 \\
\text { rho }=-0.616\end{array}$ \\
\hline $\begin{array}{l}\text { Day length } \\
\text { (on the day of tick } \\
\text { collection) }\end{array}$ & & $\begin{array}{c}\mathrm{p}<0.001 \\
\underline{\mathrm{rho}=-0.808}\end{array}$ & \\
\hline
\end{tabular}

b) Ixodes ricinus

\begin{tabular}{|c|c|c|c|}
\hline \multirow{2}{*}{ 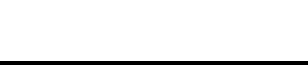 } & & & \\
\hline & $0-30$ days* & 0-10 days* & $0-5$ days* \\
\hline Mean hygrometry & $\begin{array}{c}p=0.002 \\
\text { rho=-0.560 }\end{array}$ & $\begin{array}{c}p=0.010 \\
\text { rho }=-0.4798062\end{array}$ & $\begin{array}{c}\mathrm{p}=0.048 \\
\text { rho }=-0.377\end{array}$ \\
\hline Mean temperature & $\begin{array}{c}\mathrm{p}<0.001 \\
\mathrm{rho}=0.668\end{array}$ & $\begin{array}{c}\mathrm{p}<0.001 \\
\text { rho=0.717 }\end{array}$ & $\begin{array}{c}\mathrm{p}<0.001 \\
\mathrm{rho}=0.680\end{array}$ \\
\hline Mean wind speed & $\begin{array}{c}\mathrm{p}=0.108 \\
\mathrm{rho}=-0.310\end{array}$ & $\begin{array}{c}\mathrm{p}=0.039 \\
\text { rho }=-0.392\end{array}$ & $\begin{array}{c}p=0.030 \\
\text { rho }=-0.412\end{array}$ \\
\hline $\begin{array}{c}\text { Mean saturation } \\
\text { deficit }\end{array}$ & $\begin{array}{c}\mathrm{p}<0.001 \\
\text { rho=0.704 }\end{array}$ & $\begin{array}{c}\mathrm{p}<0.001 \\
\mathrm{rho}=0.599\end{array}$ & $\begin{array}{c}\mathrm{p}=0.002 \\
\text { rho }=0.553\end{array}$ \\
\hline $\begin{array}{l}\text { Day length } \\
\text { (on the day of tick } \\
\text { collection) }\end{array}$ & & $\begin{array}{c}\mathrm{p}=0.004 \\
\mathrm{rho}=0.527\end{array}$ & \\
\hline
\end{tabular}

* prior to the day of tick collection

For each meteorological factor and time interval prior to tick collection, and for day length on the day of tick collection, the relationship with larval counts was estimated by Spearman's rank correlation, with indication of p-value (p) and rho (rho). Cells in grey indicate a significant correlation $(\mathrm{p} \leq 0.05)$. For each meteorological factor, the cell in bold indicates the most relevant time interval to be considered. The cell with the best correlation is underlined.

Meteorological variables, day length and larval counts were considered from February 2015 to May 2017 (28 dates) for the whole observatory. 


\section{Table 2}

Summary of general linear models explaining log-transformed Ixodes frontalis and Ixodes ricinus larval counts (log(larval count+1))

\begin{tabular}{|c|c|c|c|c|c|c|c|c|}
\hline & & \multicolumn{7}{|c|}{ Ixodes frontalis } \\
\hline & & Estimate & $\mathrm{SE}$ & $t$ & $p$ & & $\mathrm{R}^{2}$ & AIC \\
\hline \multirow{2}{*}{$\begin{array}{c}\text { Meteorological } \\
\text { model }\end{array}$} & Intercept & 6.18125 & 0.81965 & 7.541 & $<0.001$ & $* * *$ & \multirow{2}{*}{0.4693} & \multirow{2}{*}{110.1175} \\
\hline & Mean temperature $(0-10 \text { days })^{\circ}$ & -0.31205 & 0.06507 & -4.795 & $<0.001$ & *** & & \\
\hline \multirow{2}{*}{ Seasonal model } & Intercept & 11.11442 & 0.98589 & 11.274 & $<0.001$ & $* * *$ & \multirow{2}{*}{0.7531} & \multirow{2}{*}{$\mathbf{8 8 . 6 9 4 9 6}$} \\
\hline & Day length" & -0.69772 & 0.07835 & -8.905 & $<0.001$ & $* * *$ & & \\
\hline \multirow{3}{*}{$\begin{array}{l}\text { Combined } \\
\text { model }\end{array}$} & Intercept & 10.91245 & 1.03358 & 10.558 & $<0.001$ & $* * *$ & \multirow{3}{*}{0.7388} & \multirow{3}{*}{90.11617} \\
\hline & Mean temperature $(0-10 \text { days })^{\circ}$ & -0.04765 & 0.06595 & -0.723 & 0.477 & & & \\
\hline & Day length\# & -0.63600 & 0.11640 & -5.464 & $<0.001$ & $* * *$ & & \\
\hline \multirow{4}{*}{$\begin{array}{c}\text { Combined } \\
\text { model } \\
\text { with } \\
\text { interaction }\end{array}$} & Intercept & 7.29429 & 3.36400 & 2.168 & $<0.05$ & * & \multirow{4}{*}{0.7416} & \multirow{4}{*}{90.66578} \\
\hline & Mean temperature $(0-10 \text { days })^{\circ}$ & 0.29308 & 0.30869 & 0.949 & 0.3519 & & & \\
\hline & Day length" & -0.33442 & 0.29100 & -1.149 & 0.2618 & & & \\
\hline & Interaction & -0.02665 & 0.02359 & -1.130 & 0.2698 & & & \\
\hline
\end{tabular}

\begin{tabular}{lcccccc}
\multicolumn{7}{c}{ Ixodes ricinus } \\
\hline Estimate & $\mathrm{SE}$ & $t$ & & $p$ & $\mathrm{R}^{2}$ & AIC \\
& & & & & & \\
\hline $\mathbf{- 1 . 3 6 6 3 5}$ & $\mathbf{0 . 7 3 8 5 9}$ & $\mathbf{- 1 . 8 5 0}$ & $\mathbf{0 . 0 7 5 7}$ &. & $\mathbf{0 . 5 3 2 8}$ & $\mathbf{1 0 4 . 2 8 5 7}$ \\
$\mathbf{0 . 3 1 9 3 0}$ & $\mathbf{0 . 0 5 8 6 4}$ & $\mathbf{5 . 4 4 5}$ & $<\mathbf{0 . 0 0 1}$ & $* * *$ & & \\
\hline-2.5494 & 1.6302 & -1.564 & 0.1300 & & 0.268 & 116.8585 \\
0.3997 & 0.1296 & 3.085 & $<0.01$ & $* *$ & & \\
\hline-1.14317 & 1.37854 & -0.829 & 0.4148 & & & \\
0.33178 & 0.08796 & 3.772 & $<0.001$ & $* * *$ & 0.4962 & 106.2439 \\
-0.03000 & 0.15525 & -0.193 & 0.8483 & & & \\
\hline-2.81454 & 4.59050 & -0.613 & 0.5460 & & & \\
0.48917 & 0.42124 & 1.161 & 0.2570 & & 0.4784 & 108.0738 \\
0.10931 & 0.39709 & 0.275 & 0.7850 & & & \\
-0.01231 & 0.03219 & -0.382 & 0.7060 & & & \\
\hline
\end{tabular}

- prior to the day of tick collection.

\# on the day of tick collection.

For each explanatory variable, the parameter estimate, the standard error (SE), the $t$ value (test statistics) and the $p$ value (significance codes: $0{ }^{\circ * * *} 0.001^{\prime * * \prime} 0.01^{\prime * \prime} 0.05{ }^{\prime \prime} 0.1^{\prime \prime} 1$ ) are given

For the whole model, $\mathrm{R}^{2}$ and AIC are given.

For Ixodes frontalis, the seasonal model was selected as the best model according to AIC (in bold).

For Ixodes ricinus, the meteorological model was selected as the best model according to AIC (in bold). 


\section{Table 3}

Habitat preference of Ixodes frontalis compared to Ixodes ricinus on two types of transects: with bamboo versus without bamboo.

a) cumulative larval counts*

* Larvae were systematically identified on each transect from 18/02/2015 to 16/05/2017 (last 28 dates): only these dates were considered.

Cumulative larval counts

(last 28 dates: $18 / 02 / 2015$ to $16 / 05 / 2017$ )

Transects with bamboo

$\left(n^{\circ} 8, n^{\circ} 9, n^{\circ} 10\right)$

1720

376
Ixodes frontalis

Ixodes ricinus
Transects without bamboo

$\left(n^{\circ} 1, n^{\circ} 2, n^{\circ} 3, n^{\circ} 4, n^{\circ} 5, n^{\circ} 6, n^{\circ} 7\right)$
Transects with bamboo

$\left(n^{\circ} 8, n^{\circ} 9, n^{\circ} 10\right)$
8

1487

b) cumulative nymphal counts

Cumulative nymphal counts

(36 dates: 26/06/2014 to 16/05/2017)
1436

Ixodes ricinus

1088

Transects without bamboo

$\left(n^{\circ} 1, n^{\circ} 2, n^{\circ} 3, n^{\circ} 4, n^{\circ} 5, n^{\circ} 6, n^{\circ} 7\right)$

c) cumulative adult counts

Cumulative adult counts

(36 dates: $26 / 06 / 2014$ to $16 / 05 / 2017)$

Ixodes frontalis

Ixodes ricinus
Transects with bamboo

$\left(n^{\circ} 8, n^{\circ} 9, n^{\circ} 10\right)$
Transects without bamboo

$\left(n^{\circ} 1, n^{\circ} 2, n^{\circ} 3, n^{\circ} 4, n^{\circ} 5, n^{\circ} 6, n^{\circ} 7\right)$
22
32 